\title{
ENVIRONMENTAL IMPACT OF COVID-19 PANDEMIC IN INDIA
}

\author{
Nirupam Roy and Radha Chaube* \\ Department of Zoology, Banaras Hindu University, Varanasi (U.P.), India \\ *Corresponding author: chauberadha@rediffmail.com
}

\author{
Article Info: \\ Review Article \\ Received \\ 30.11.2020 \\ Reviewed
}

25.12.2020

Accepted

05.01.2021

\begin{abstract}
The ongoing pandemic caused by COVID-19 virus has paralyzed everyday life across the globe. To limit spread of infection, the Government of India issued a Nation-wide lockdown, on March $24^{\text {th }}$, which ensued a complete halting of human activities in India. Soon reports of unusual drops in pollution levels and rare animal sightings were recorded by the media. In this review article, authors explore both direct and indirect environmental impacts of this pandemic. With a halt in manufacturing industries and automobiles plying, air pollution levels went down drastically. Water pollution levels were also recorded to be on the down trend. Unusual sightings of the Himalayas from towns, hundreds of kilometers away were a sight missed for several decades, exemplifying the effect of drop in particulate matter that reduce long range visibility. With the increase in COVID cases, more and more biomedical wastes were also produced, causing a major biomedical hazard threat to an infrastructure not built to handle such volumes of infective wastes. The extent of the environmental impact of this pandemic is too soon to be assessed properly, but this review delineates the initial environmental impact that this deadly pandemic has thrown upon mankind.
\end{abstract}

Keywords: COVID-19, Environmental impact, Lockdown, Pandemic.

\section{INTRODUCTION}

The threat of a public health crisis in the form of a pandemic with the advent of the 2019 novel Corona Virus (2019-nCoV) also dubbed as SARSCoV-2 has spread fast from its provenance in Wuhan City of Hubei Province of China to the entire world in a matter of weeks (Singhal, 2020). On $31^{\text {st }}$ December, 2019, the Chinese Government relayed to the World Health Organization (WHO) the extent of pneumonia like cases amongst retailers of Huanan seafood market showing unknown etiology (Srivastava and Reddy, 2020). As of $24^{\text {th }}$ May 2020 more than 5.4 million cases have been reported worldwide with a staggering death toll of more than 3,44,000. On the basis of its spread, WHO categorized the COVID-19 into four stages.These stages include Stage 1 (imported cases), Stage 2 (local transmission), Stage 3 (community transmission) and Stage 4 (transmission out of control). The virus spread exponentially in Italy, China, Spain and America which saw Stage 3 Community Transmissions (Kumari and Shukla, 2020).

The Indian Government with a rise in cases issued a countrywide lockdown starting from midnight of $24^{\text {th }}$ March, 2020 in a bid to arrest cases by enforcing social distancing (Pulla, 2020). 
Extensive restrictions in travel were implemented probably for the first time since World War II, with all eateries, theatres and pubs being closed around the globe.Worldwide flights are being cancelled or returned mid-air, crumbling the aviation sector with international tourists stuck mid-holiday. India with \$2.94 trillion economy (by IMF) ranked $5^{\text {th }}$ among the highest polluted countries, now under lockdown stares at both public health and an economic shock. The subsequent lockdown meant cessation of almost all non-essential industrial activities and a sudden drastic drop in human traffic in and around the busy cities due to closure of almost all non-governmental and governmental offices with a strict "Work-FromHome Policy”(Roy et al., 2020).

With the restriction of movement, closure of factories and curfew timings, the environment seemed to alter itself from the routine of anthropogenic pollution. Increased animal sightings due to lack of human movements have been reported from around the world. Reports have been published about the lowering of pollution levels post-lockdown. However, on the other hand, a monumental increase in medical waste has posed a threat to the environment, adding the fear of re-infection as well as inadequate logistics for its disposal (Yu et al., 2020). Here, in this article authors discuss the various environmental impacts of COVID-19.

\section{AIR POLLUTION}

\section{Reduced Carbon Emission}

With the closure of factories and restriction of vehicle movement there has been a significant impact on the carbon emissions, with China reporting a $25 \%$ reduction in its carbon emissions. Kolkata, a metropolitan city in Eastern India with a population of 14.9 million that nears the global $\mathrm{CO}_{2}$ emission average of $417.31 \mathrm{ppm}$ (https://www.co2.earth/) as per the record of $30^{\text {th }}$ April, 2020, recorded a significant decrease in $\mathrm{CO}_{2}$ emissions post lockdown with an average of more than $40 \%$ reduction in emissions as sampled from three different locations (Dhar et al., 2020). Another independent study shows a range of decrease percentage in $\mathrm{CO}_{2}$ emissions in Kolkata from $24.56 \%$ (at Deshbandhu Park) to
45.37\% (at Sealdah Station). This range can be attributed to the density of vegetation in the different sampling areas (Mitra et al., 2020a).

India, the second largest coal consumer, recorded a massive yearly decline in power generation in April 2020. With about 19\% reduction in average daily power generation, there was a concomitant decrease in Industrial Coal demand with purchasing index dropping from 51.8 in March to 27.4 in April.

\section{Air Quality Index}

The Central Pollution Control Board (CPCB) along with State level pollution monitoring centres operates the NAMP (National Air Monitoring Program) that records the AQI of 24 cities across India based on eight parameters, (PM10, PM2.5, $\mathrm{NO}_{2}, \mathrm{SO}_{2}, \mathrm{CO}, \mathrm{O}_{3}, \mathrm{NH}_{3}$, and $\mathrm{Pb}$ ). High concentrations of such pollutants cause serious environmental hazards. Nox in particular can cause nutrient pollution in coastal areas, acid rain formation and smog. $\mathrm{NO}_{2}$ acts as an indicator for all Nox gases. $\mathrm{NO}_{2}$ emission is mostly credited to fuel usage in power-stations and from automobile exhausts (Wang and $\mathrm{Su}, 2020$ ).

According to new satellite images taken by ESA (European Space Agency) from its Copernicus Sentinel-5P satellite, Mumbai and Delhi, the two main metropolitan cities of India, showed drops of about $40-50 \%$ in tropospheric $\mathrm{NO}_{2}$ columns compared to the same time frame from 2019. NASA's Terra satellite retrieved data from its Moderate Resolution Imaging Spectroradiometer (MODIS) showed Aerosol anomaly post lockdown over India. Aerosols produced by the automobiles, power-plants and industrial coal usage contribute to the majority of Aerosol emission in the Gangetic plains.

A study based on the NAQI (National Air Quality Index) around NCT of Delhi showed a significant decrease in pollutants during the lockdown (study period till $14^{\text {th }}$ April 2020). With an average concentration of PM10 and PM2.5 showing negative changes amidst lockdown from $-51.84 \%$ and $-53.11 \%$ respectively, even other pollutants $\mathrm{NO}_{2}(-52.68 \%)$ and $\mathrm{CO}(-30.35 \%)$ have shown considerable negative change in concentration (Mahato et al., 2020). Relative to 


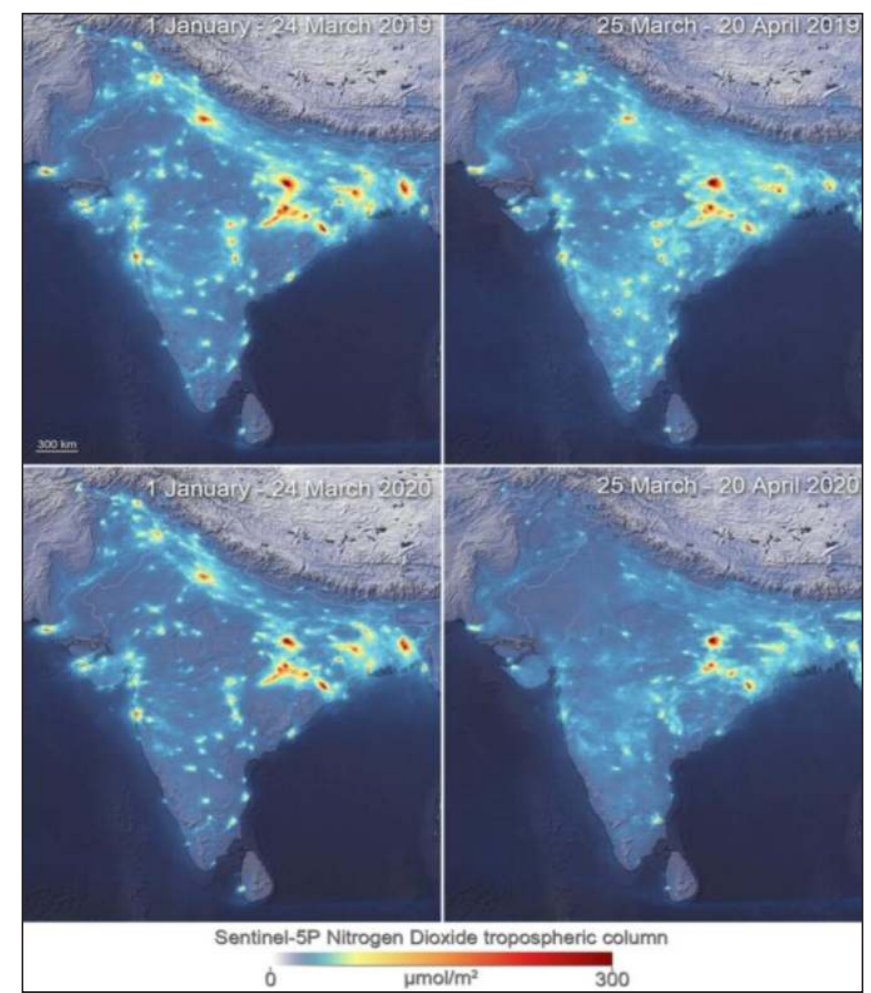

Figure 1: Nitrogen Dioxide concentrations (Source: ESA)

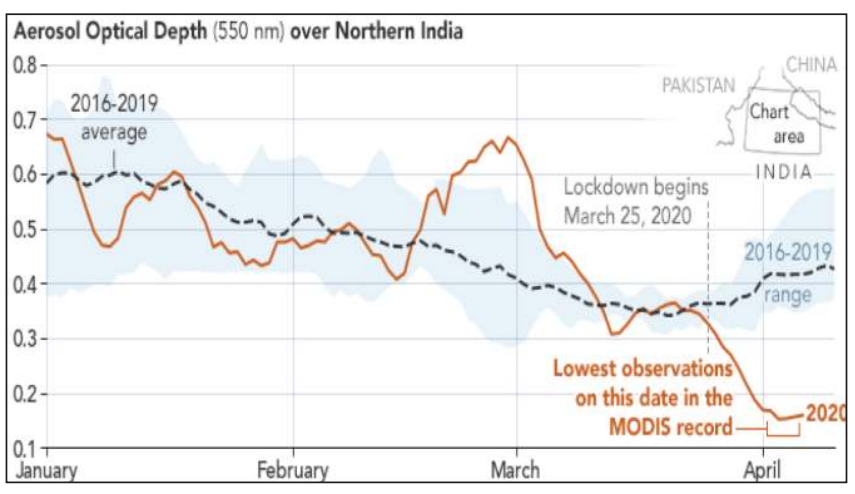

Figure 3: Aerosol Optical Depth Chart. (Source: NASA)

these trends $\mathrm{SO}_{2}(-17.97 \%)$, and $\mathrm{NH}_{3}(-12.33 \%)$ showed lowered reduction, with $\mathrm{O}_{3}(+0.78 \%)$ showing minimal but positive increased change. This can be attributed to the lowering of NO levels which acts as scavengers for $\mathrm{O} 3[\mathrm{NO}+\mathrm{O} 3$ $=\mathrm{NO} 2+\mathrm{O} 2]$. (Mahato et al., 2020).

CPCB Notification detailed that $47 \%$ reduction in Benzene levels have been recorded in Delhi. In NCR towns there has been an overall reduction of over 48\% in PM10 and PM2.5 levels during the lockdown period. Recorded sharp improvement in Faridabad has been seen with 55\% reduction in PM2.5 levels and Gurugram with 54\% reduction

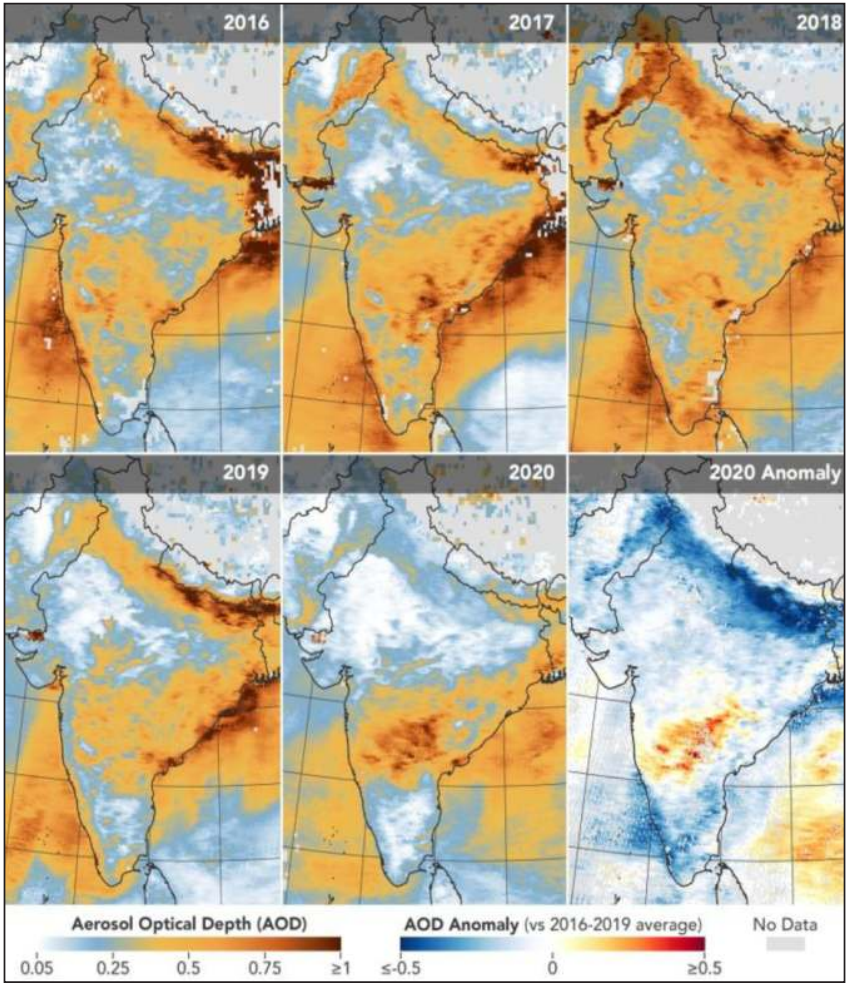

Figure 2: Aerosol Optical Depth and anomaly as seen in lockdown. (Source: NASA)

in PM10 levels. $\mathrm{NO}_{2}$ levels saw significant decrease in Noida (68\%), Ghaziabad (60\%) and Gurugram (40\%). However, lower change observed in Faridabad (17\%), where $\mathrm{NO}_{2}$ emissions were found relatively higher, probably due to the gas-based power plants in and around Faridabad (CPCB).

Bengaluru also known as the silicon valley of India is one of the top most polluted metropolitan cities in India. However, a study of this city in Karnataka, showed a turn in its AQI index during lockdown with respect to levels of previous years, showing "Satisfactory" from "Moderate" levels. Significant reduction in PM10 and NO2 levels were observed during the lockdown period, with $44 \%$ reduction in PM10 and $21 \%$ reduction in $\mathrm{PM} 2.5$, a $53 \%$ reduction in $\mathrm{NO}_{2}$ levels and $48 \%$ reduction in Benzene levels (CPCB).

The Super Cyclonic Storm 'Amphan' that developed over the Bay of Bengal, regarded as the most severe storm in the Gangetic Delta since 1999 Odisha Cyclone, made landfall in West Bengal on 20th May, 2020 during the nationwide lockdown amidst the COVID Pandemic causing widespread damages. There have been reports that suspect such severity of the storm to be 


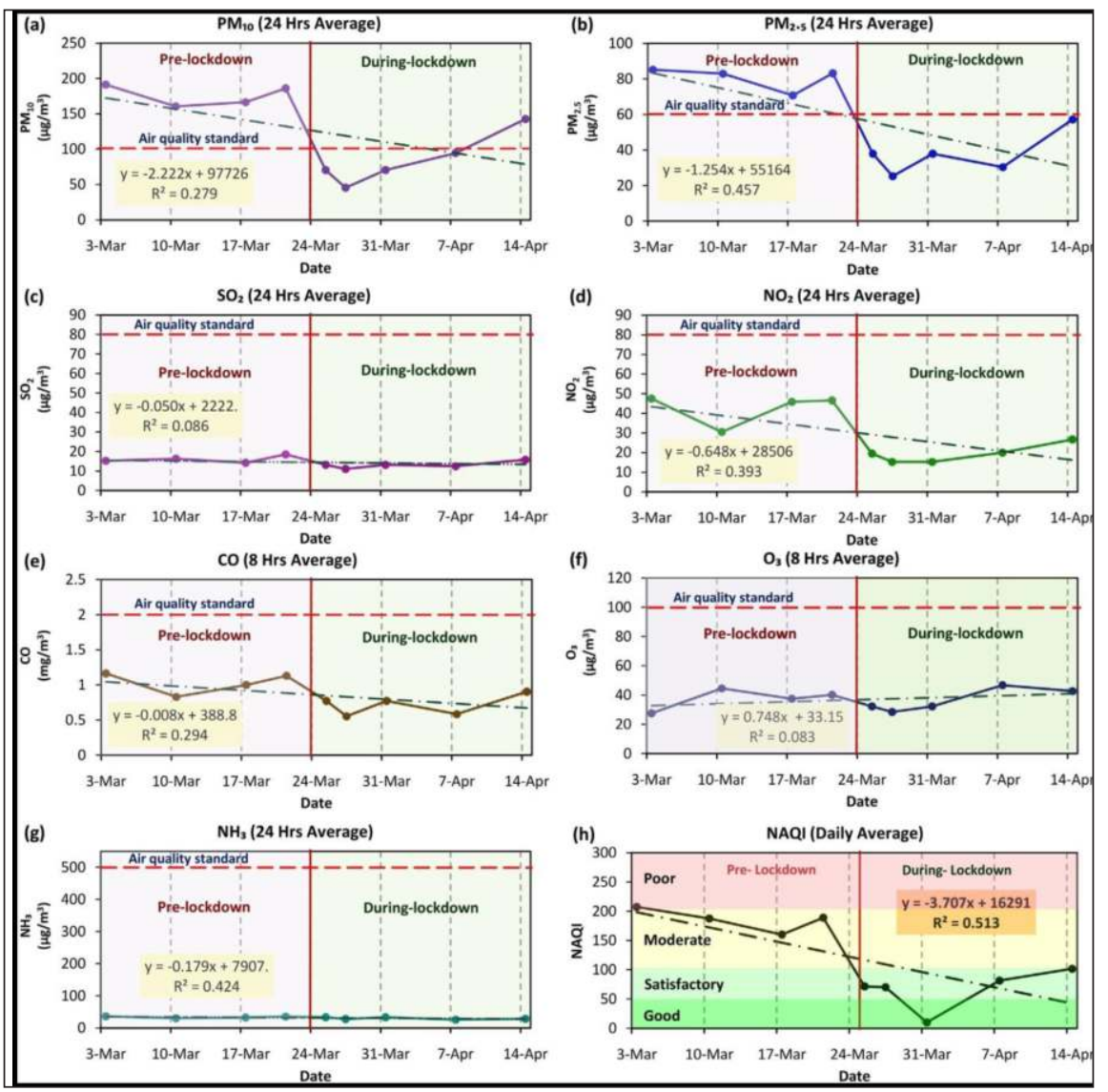

Figure 4: Trend of $24 \mathrm{~h}$ average concentrations of (a) PM10, (b) $\mathrm{PM}_{2.5}$, (c) $\mathrm{SO}_{2}$, (d) $\mathrm{NO}_{2}$, (g) $\mathrm{NH}_{3} \&$ (h) NAQI and $8 \mathrm{~h}$ average daily maxima of (e) $\mathrm{CO} \&$ (f) $\mathrm{O}_{3}$ between 3rd March and 14th April (lockdown started on 24th March) in NCT (Delhi, India) (Source: Mahato et al., 2020)

\begin{tabular}{|l|c|c|c|c|c|c|c|}
\hline Date & $\begin{array}{c}\text { Predominant } \\
\text { Wind Speed } \\
\text { (kmph) }\end{array}$ & $\begin{array}{c}\text { Maximum } \\
\text { Mixing } \\
\text { Height } \\
(\mathbf{m})\end{array}$ & Delhi & Ghaziabad & Noida & Faridabad & Gurugram \\
\hline 16-Mar & 16 & 1800 & 139 & 134 & 118 & 184 & 165 \\
\hline 17-Mar & 12 & 1500 & 157 & 148 & 140 & 164 & 141 \\
\hline 18-Mar & 15 & 2000 & 151 & 172 & 137 & 164 & 168 \\
\hline 19-Mar & 14 & 3200 & 186 & 236 & 184 & 194 & 192 \\
\hline 20-Mar & 12 & 2400 & 192 & 235 & 195 & 212 & 175 \\
\hline 21-Mar & 16 & 2500 & 186 & 207 & 161 & 174 & 126 \\
\hline $\begin{array}{l}\text { 22-Mar } \\
\text { (Janata }\end{array}$ & 12 & 2900 & 191 & 237 & 176 & 214 & 191 \\
\hline 2urfew) & 10 & 800 & 124 & 159 & 123 & 130 & 91 \\
\hline 24-Mar & 10 & 2700 & 122 & 166 & 130 & 187 & 127 \\
\hline \multicolumn{2}{|l|}{} & IMPOSITION OF NATIONWIDE LOCKDOWN DUE TO COVID-19 & \\
\hline 25-Mar & 12 & 2500 & 77 & 86 & 80 & 100 & 69 \\
\hline 26-Mar & 25 & 1100 & 92 & 84 & 72 & 88 & 61 \\
\hline 27-Mar & 15 & 500 & 69 & 72 & 60 & 75 & 42 \\
\hline 28-Mar & 14 & 2250 & 45 & 39 & 38 & 64 & 54 \\
\hline 29-Mar & 20 & 2600 & 62 & 48 & 58 & 83 & 62 \\
\hline 30-Mar & 20 & 2100 & 71 & 64 & 61 & 97 & 76 \\
\hline 31-Mar & 12 & 1900 & 76 & 72 & 67 & 110 & 77 \\
\hline 01-Apr & 12 & 3200 & 73 & 79 & 73 & 90 & 69 \\
\hline O2-Apr & 20 & 3050 & 69 & 63 & 62 & 63 & 72 \\
\hline 03-Apr & 22 & 2100 & 79 & 104 & 72 & 97 & 82 \\
\hline
\end{tabular}

Figure 5:Air Quality Index of NCR Delhi from 16th March, 2020 (pre-lockdown) to 3rd April, 2020 (Lock-down period). (Source: CPCB Bulletin). 


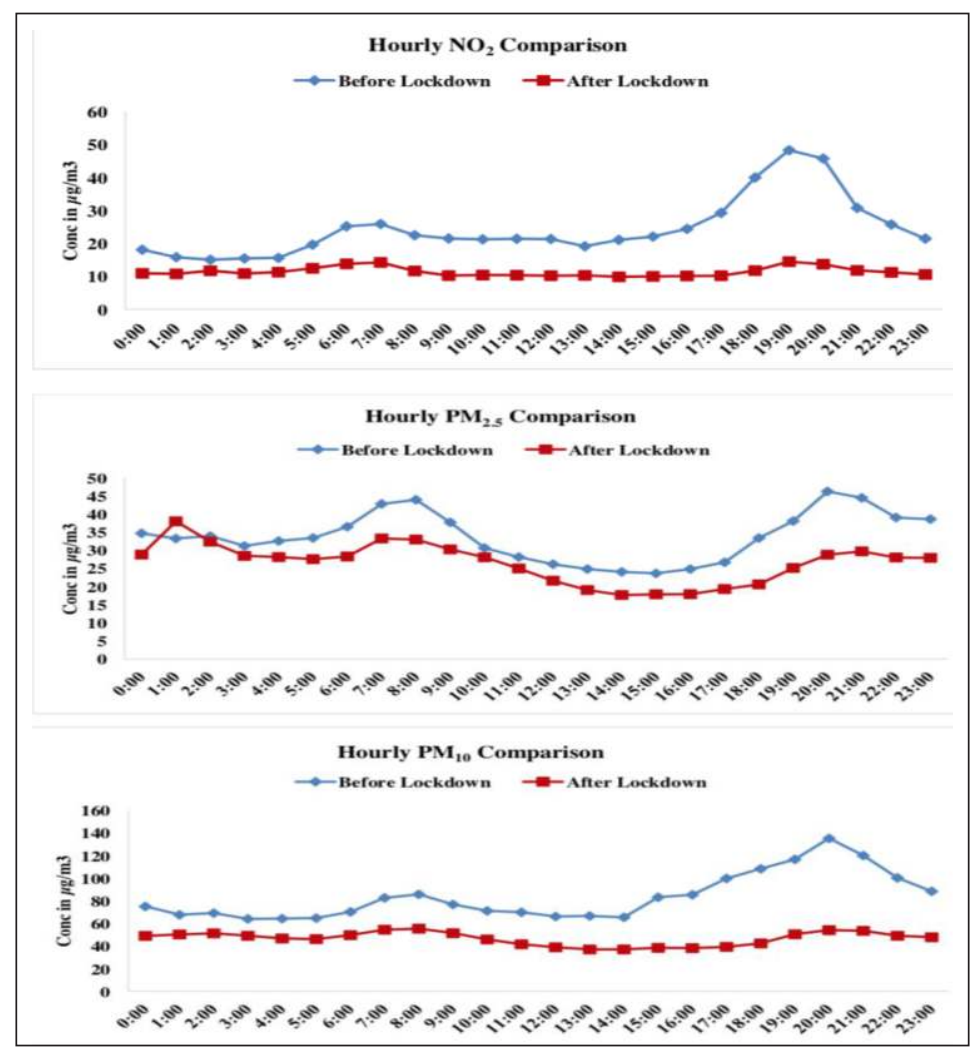

Figure 6: Air Quality Parameters comparison between Pre-Lockdown and After-Lockdown data in Bengaluru. (Source: CPCB Bulletin).

reason of the sudden climatic change impacted by the lockdown. Reports indicate at lowering of anthropogenic aerosols might have played a role in the intensification of the cyclone. A reduced pollution level and aerosol meant higher surface warming of oceans that acted as a trigger factor for the intensification of Cyclone Amphan.

\section{Visibility of the Himalayas}

The people of Jalandhar in the state of Punjab woke up on $3^{\text {rd }}$ April, to the sight of the Dhauladhar

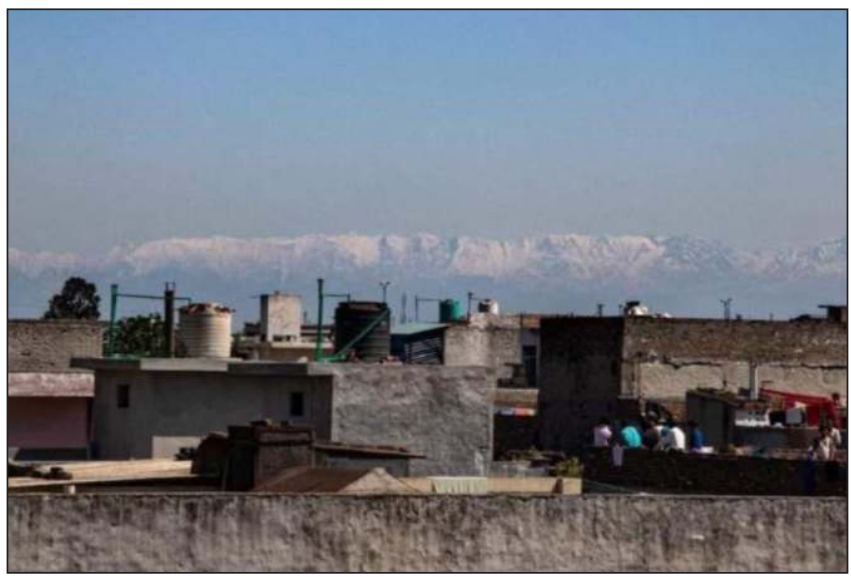

Figure 7a: Himalayas visible from the city of Jalandhar (Source: CNN). mountain ranges of the Himalayas, with their snow capped peaks visible from their roof tops. On April $29^{\text {th }}$, an IFS officer took to twitter a picture of the Gangotri Peaks of the Himalayas, visible from the town of Saharanpur, Uttar Pradesh. This serene view is said to have been witnessed after three decades. The Bandarpoonch mountain massif in the Garhwal region standing at 6313 meters above sea level was visible to the residents of Saharanpur to the naked eye, its snow-clad peaks glistening in the setting sun.

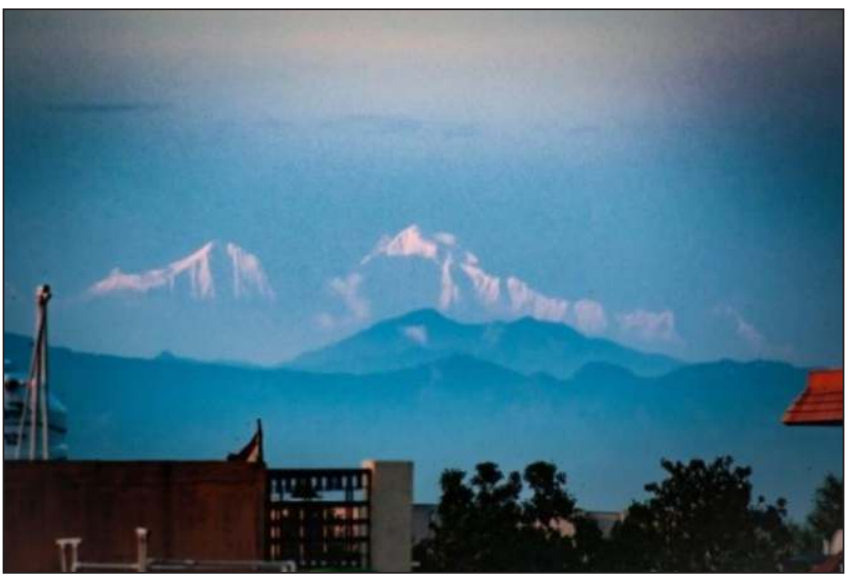

Figure 7b: Gangotri peaks visible from Saharanpur. (Source: Financial Express). 


\section{WATER POLLUTION}

\section{Impact on River Ganga}

The life-line of India, the River Ganga, with 97 towns along its course copes with 3500 MLD (million litres per day) of sewage, of which about 9\% accounts for industrial effluents. During the nationwide lockdown, there has been an overall improvement on the water quality with respect to the increased Dissolved Oxygen (DO) and decreased Nitrate concentration. This is mainly due to the absence of industrial discharge and agricultural runoff as well as increased freshwater input. There was recorded less Biological Oxygen Demand (BOD) as well as Chemical Oxygen Demand (COD) due to relatively less domestic wastewater influx. [Source: CPCB Report]. The water of Rapti, Saryu, Ganga and Yamuna rivers in cities also became clear and transparent due to less deposition of domestic and industrial effluents (Verma and Prakash, 2020a).

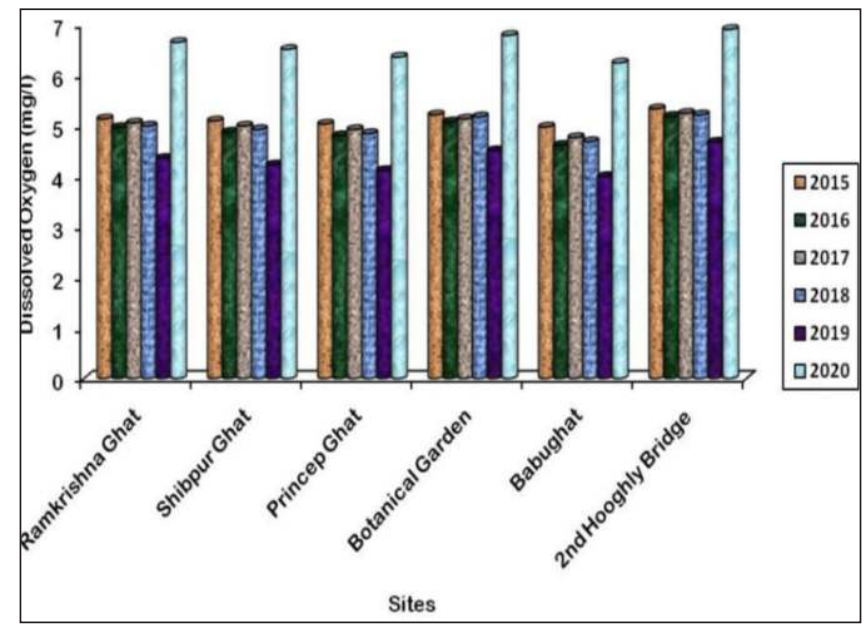

Figure 8: Spatial variation of DO level (in $\mathrm{mg} / \mathrm{l}$ ) in River Ganga. (Dhar et al., 2020).

A study on Dissolved Zinc concentrations in the Estuarine System of Hooghly, which is an offshoot of Ganga, showed significant changes in the post-lockdown period. In all three sampling stations of Kakdwip, Shankarpur and Bony camp, the investigation showed a sudden dip in the otherwise increasing trend of dissolved Zinc all through the 1st to 4th week April, 2020 (Agarwal et al., 2020).

With increased climatic change and waste water disposal, Ganga has seen a concomitant increase in acidification of its waters with increase in its dissolved $\mathrm{CO}_{2}$ content (Dutta et al., 2020). Post-
Dissolved Oxygen concentrations remained above bathing water criteria norms ( $5 \mathrm{mg} / \mathrm{l}$ or more) at all locations during the lockdown period, however only marginal improvement was seen in most stations along Uttar Pradesh, and significant improvement in only a few monitoring stations (i.e. in West Bengal) only after the 2nd week of lockdown. Marginal reduction in BOD was seen in only the $4^{\text {th }}$ week onwards. A decreased trend of Nitrate concentration was recorded (except in West Bengal). [Source: CPCB Report]

A study conducted along six ghats in and around Kolkata, showed significant increases in DO postlockdown. DO increment of $35.71 \%, 35.06 \%$, 33.97\%, 35.06\%, in Princep Ghat, Botanical Ghat, Babughat and $2^{\text {nd }}$ Hooghly Bridge respectively during April, 2020 was recorded (Dhar et al., 2020).

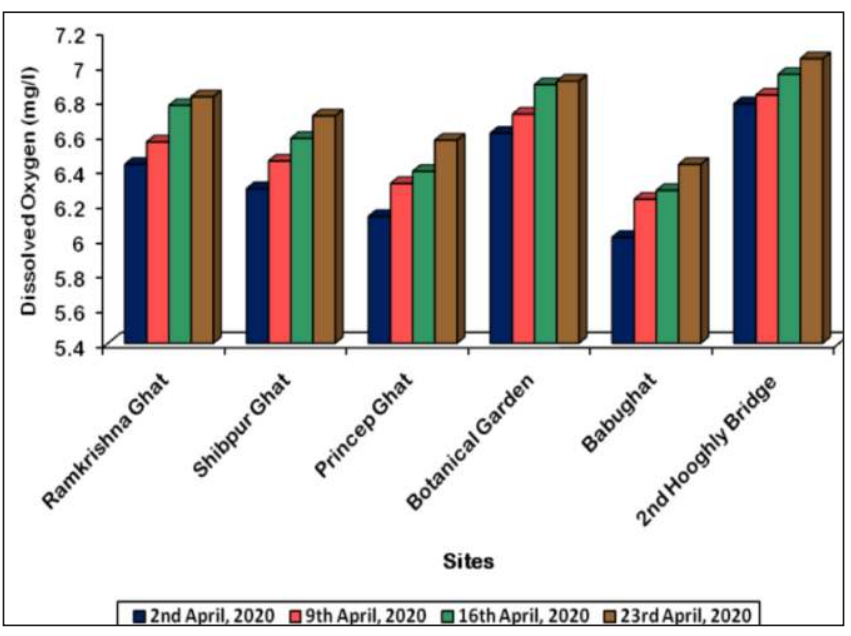

Figure 9: DO level (in $\mathrm{mg} / \mathrm{l}$ ) in the study sites during lockdown phase (Dhar et al., 2020).

lockdown investigation from three points along the banks of Hooghly River in Kolkata showed a reversal in acidification from all three sites. The data set from 18th March (Pre-lockdown) to 30th April (Post-lockdown) showed 2.84\%, 3.46\% and $4.99 \%$ at Ramakrishna Ghat, Botanical garden and Babughat, respectively. This might be due to the complete stoppage of industrial discharge as well as absence of fishing trawlers and recreational activities along the ghats (Mitra et al., 2020b).

With news on social media circulating about a sudden clean Yamuna front, the CPCB team 


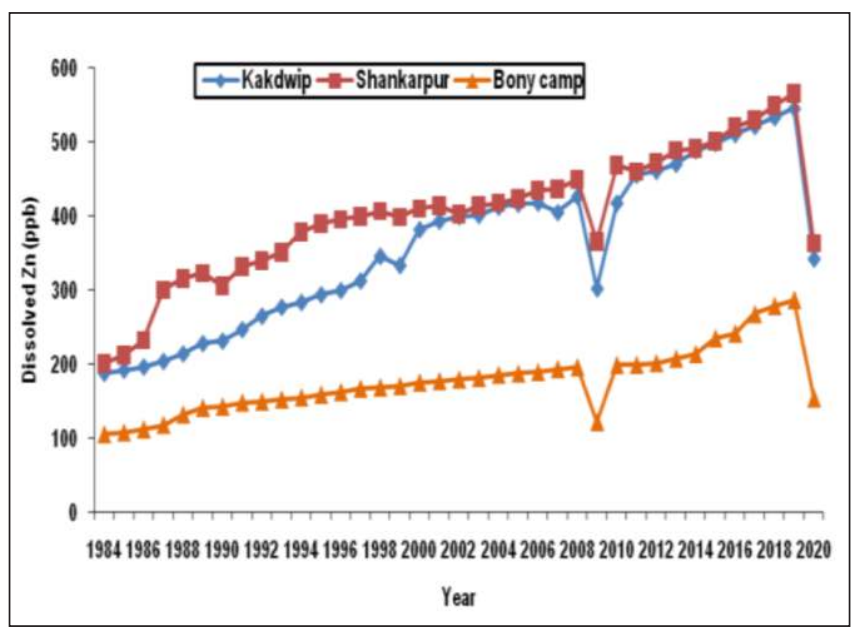

Figure 10: Variation of dissolved $\mathrm{Zn}$ during the study period (1984-2020). (Agarwal et al., 2020).

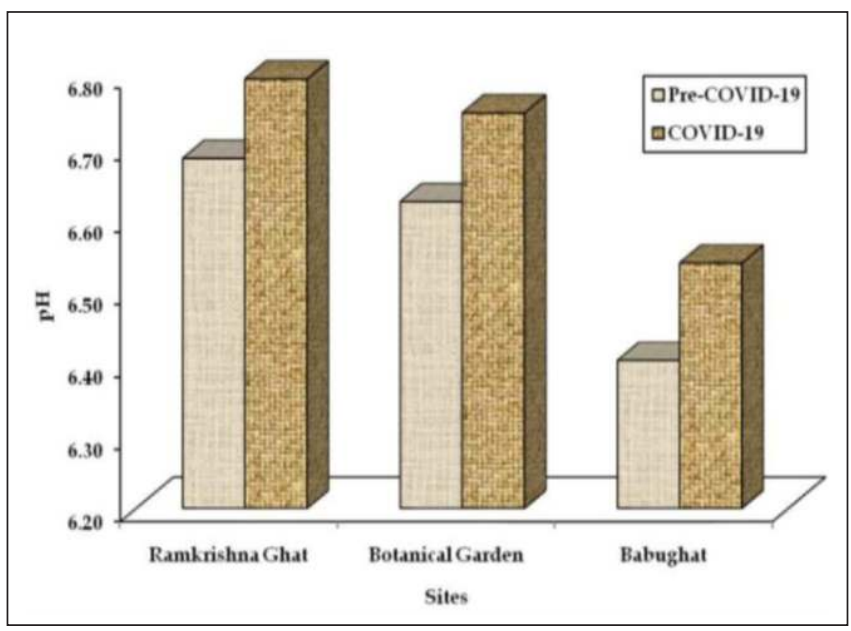

Figure 12: $\mathrm{pH}$ variation in the three selected sampling sites between pre-COVID-19 and COVID-19 lockdown period. (Mitra et al., 2020b)

conducted tests along the river at focal points in NCT Delhi. The results showed considerable improvement in the water quality in Yamuna (with respect to DO, BOD and COD). This improvement can be credited to:
a) Release of fresh water from Wazirabad Barrage
b) Absence of Industrialdischarge ( 35.9 MLD pre-lockdown)
c) High Solar penetration in water-clearing out the settle able colloids in river bed.
d) Absence of human activities along the banks. Figure 13: Figure : Water Quality Trend of River Yamuna and Two Drains with respect to COD (during Pre-Lockdown and Lockdown )

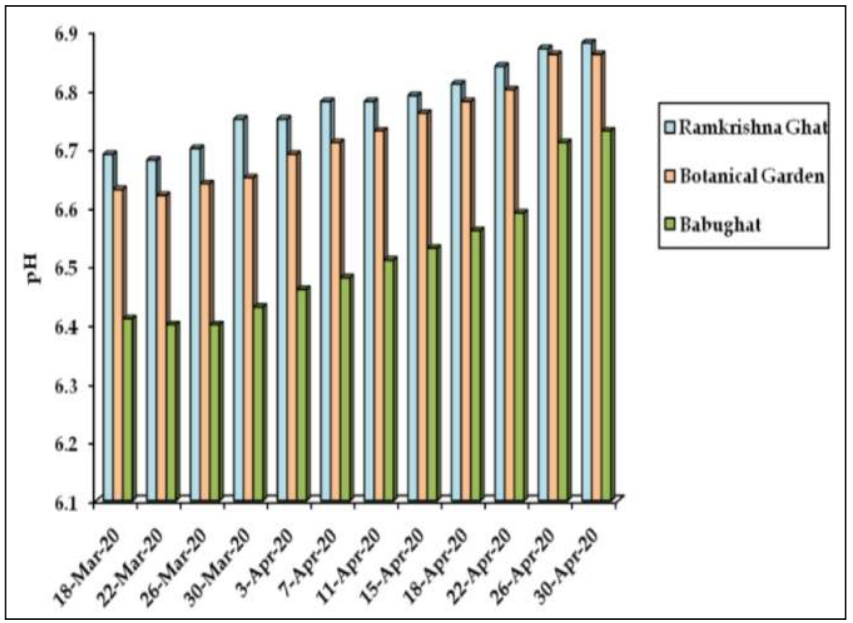

Figure 11: Spatiotemporal variation of $\mathrm{pH}$ during the study period. (Mitra et al., 2020b)

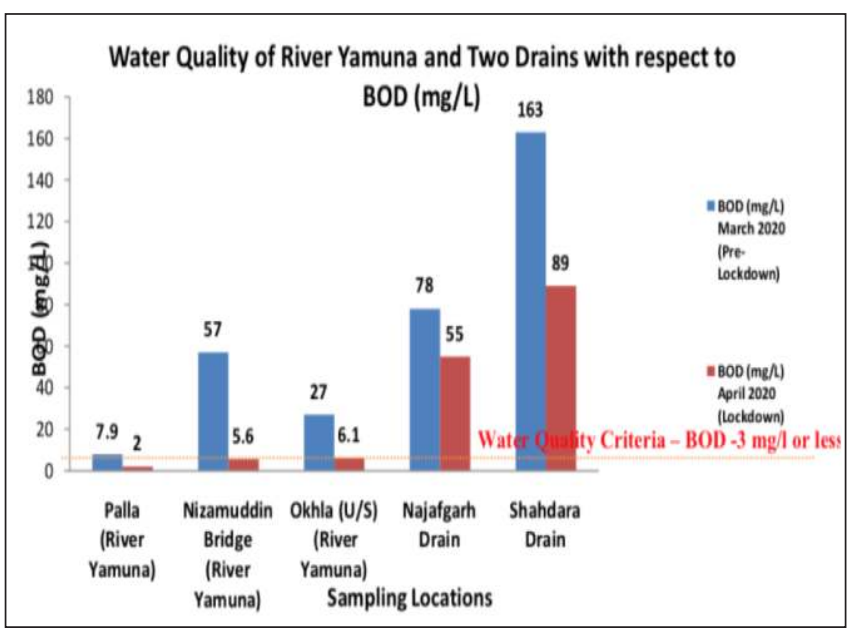

Figure 13: Figure : Water Quality Trend of River Yamuna and Two Drains with respect to COD (during Pre-Lockdown and Lockdown) Source: CPCB Bulletin

\section{IMPACT ON BIOLOGICAL LIFE}

A study on Ichthyoplankton community around the Haldia port-cum industrial complex showed eco-restoration of the community due to lower oil-grease pollution in the estuarine area due to lockdown (Pal et al., 2020). A similar study in Diamond Harbour along Hooghly estuary concluded a higher standing stock of phytoplankton in April, 2020.

With reports surfacing about spotting rare sights of Gangetic Dolphins around Babughat (Kolkata), to Meerut, even critically endangered species of Malabar Large Spotted Civet made the rounds of news after being spotted in the streets of Kozhikode, Kerala. It seems that increased visibility of these animals is to be credited to the 
lack of human traffic in these areas and reduced levels of pollution.

In the Therthangal and MelaselvanoorKeelaselvanoor bird sanctuary, in Ramanathapura Forest Range, forest officials observed extended stay of partial-migratory birds like open bill stork, spot-billed pelican, painted stork, grey heron, spoonbill and ibis, thanks to the clean air and low noise pollution in and around the area. In Mumbai, a record breaking 1,50,000 flamingoes migrated, turning the wetlands in a picturesque pink hue.

\section{BIO-MEDICAL WASTES}

Both electronic and biomedical wastes are big problems for biodiversity and humans (Verma and Prakash, 2020b). The sheer amount of biomedical waste that is being produced due to the uprise in COVID-19 numbers is slowly turning into a waste management nightmare. PPEs, N95 masks, gloves, disposable bedsheets make up most of the biomedical waste generated in the pandemic. Compared to a normal patient, a COVID patient produces around $14 \mathrm{~kg}$ of biomedical waste a day. Instances of used face masks being picked up by rag-pickers in Pune were reported. In Thane, a man was arrested for drying up 1,00,000 used face-masks for reselling. Unauthorized waste segregation of masks, used syringes and PPE was reported at the Rohingya refugee camp site of the Sharan Vihar camp, near Kalindi Kunj (Delhi). Blue medical waste bags flooded the area, ready for segregation to be later sold as plastic waste. If not disposed of properly, face masks and other medical wastes can act as a source of reinfection. The CPCB issued guidelines for the proper disposal of medical waste on $18^{\text {th }}$ March, 2020. Colour coding of waste bins, using double layered bags, proper waste inventory and disinfection by using $1 \%$ Sodium Hypochlorite solution were some of the main directives (CPCB).

\section{DISCUSSION}

In this review, authors observed how a pandemic forced humans across the entire world to close its doors, and how the nature flourished. In the Indian perspective, authors took account for all the environmental impacts and observed decreasing air pollution, water pollution and animal sightings. With a boon for nature during this pandemic, medical wastes also have multiplied threatening more plastic wastes in the environment, along with a risk of re-infection. The long term effects of this lockdown on the environment due to this pandemic is yet to be ascertained, however it is evident from the shortterm data that nature has seen significant impact of the lockdown as a safety measure from the pandemic, due to highly reduced human movement and anthropogenic activities. Although, environmental improvement should not be rejoiced when the entire world is gripped by this horrible pandemic, humans should in this moment gauze the impact that anthropogenic activities have on the environment, or lack thereof. This pandemic showed humanity how much there is a need for sustainable development, and how much our environment can benefit from it. As mankind grapples for breath, Nature seems to heal.

\section{BIBLIOGRAPHY}

1. Article on arrest due to dumping of used face mask in open-space. https:// timesofindia.indiatimes.com/videos/city/mu mbai/mumbai-man-arrested-for-dumpingused-face-masks-in-open-space/videoshow/ 74590346.cms

2. Article on Central Pollution Control Board (2020) Guidelines for handling, Treatment, Disposal of Waste generated during Treatment/Diagnosis/Quarantine of COVID19 Patients. https://www.cpcb.nic.in /uploads/Projects/Bio-Medical-Waste/BMWGUIDELINES-COVID.pdf

3. Article on Coronavirus: Stranded tourists 'living off noodles' (2020) BBC. https://www.bbc.com/news/uk-wales52255583

4. Article on Coronavirus: Stranded tourists 'living off noodles'. Argus Media. https://www.argusmedia.com/en/blog/2020/ may/5/covid-19-crushes-global-powerdemand-and-coal-consumption-in-april

5. Article on Flamingos Reportedly Descend on Mumbai Amid India's Strict Coronavirus Lockdown. Time. .https://time.com/ 5831198/flamingos-coronavirus/ 
6. Article on Guidelines on preventive measures to contain spread of COVID-19 in workplace settings. Government of India Ministry of Health \& Family Welfare Directorate General of Health. https://www.mohfw.gov.in/ pdf/Guidelinesonpreventivemeasurestocontai nspreadofCOVID19inworkplacesettings.pdf

7. Article on Himalayas visible from Saharanpur. FE Online. https:// www.financialexpress.com/lifestyle/traveltourism/now-himalayas-visible-fromsaharanpur-up-town-wakes-up-tos pectacular-view-of-snow-cappedpeaks/1944213/

8. Article on how climate change and air pollution impacted Cyclone Amphan. IANS. h t t p s : / / w e a t h e r. c o m / e n IN/india/news/news/2020-05-19-climatechange-air-pollution-impact-cycloneamphan-experts

9. Article on impact of lockdown on migratory birds. https://www.thehindu.com/ news/national/tamil-nadu/pandemicinduced-lockdown-gives-migratory-birdsa n d - a n i m a l s - a - r e a s o n - t o cheer/article31458071.ece

10. Article on lack of disposal system of used face mask. https://indianexpress.com/ article/cities/pune/coronavirus-no-systemin-place-for-disposal-of-used-face-masks6327063/

11. Article on lasting impact of Covid-19 on e n vironment. B B C Future. https://www.bbc.com/future/article/2020032 6-covid-19-the-impact-of-coronavirus-onthe-environment.

12. Article on refugees living amid medical waste at Kalindi Kunj Camp. https:// indianexpress.com/article/cities/delhi/kalind i-kunj-refugee-camp-medical-wastecoronavirus-hunger-6341211/

13. Article on spotting of Dolphins in Meerut during Lockdown.https://www.news18.com /news/buzz/endangered-gangetic-dolphinshave-been-spotted-in-meerut-as-humansstay-home-during-lockdown-2594815.html

14. Article on spotting of Gangetic Dolphin in Kolkata ghats after 30 years. https:// timesofindia.indiatimes.com/travel/thingsto-do/lockdown-effect-gangetic-dolphinss potted-at-kolkata-ghat s-after-30 years/as75375783.cms

15. Article on spotting of rare animals in cities during lockdown. https://www.news18.com/ news/buzz/national-endangered-speciesday-these-rare-animals-have-been-spottedsince-lockdown-in-cities-2620911.html

16. Article on visibility of Himalayas after decades due to lowered Air-pollution. https://edition.cnn.com/travel/article/himala y a s-vis ible-lockdown-india-scliintl/index.html

17. Article on visibility of mountain mastiff from Saharanpur. https:// www.newspost.live/ en/mountain-massif-uttarakhand-visiblesaharanpur/

18. Data on COVID-19 Demographics. worldometers.com

\section{REFERENCES}

1. Agarwal S., Pramanick P. and Mitra A. (2020). Alteration of dissolved Zinc concentration during COVID-19 lockdown phase in coastal West Bengal. NUJS Journal of Regulatory Studies. April Special Issue. 58-63.

2. Dhar I., Biswas S., Mitra A., Pramanick P. and Mitra A. (2020). COVID-19 Lockdown phase: A boon for the River Ganga water quality along the city of Kolkata. NUJS Journal of Regulatory Studies. April Special Issue. 53-57.

3. Dutta P., Pramanick P., Biswas P., Zaman S. and Mitra A. (2020). Reversing the phenomenon of acidification in the River Ganges: A Ground Zero observation. NUJS Journal of Regulatory Studies. April Special Issue. 97-100.

4. Kumari T. and Shukla V. (2020). Covid-19: Towards Confronting an Unprecedented Pandemic. International Journal of Biological Innovations. 2(1):1-10.https://doi.org/ 10.46505/IJBI.2020.2101

5. Mahato S., Pal S. and Ghosh K.G. (2020). Effect of lockdown amid COVID-19 pandemic on air quality of the megacity Delhi, India. The Science of the total environment. 730:139086. https://doi.org/10.1016/j.scitotenv.2020.13908 6 
6. Mitra A., Chadhuri T. R., Mitra A., Pramanick P. and Zaman S. (2020a). Impact of COVID-19 related shutdown on atmospheric carbon dioxide level in the city of Kolkata. Parana Journal of Science and Education. 6(3): 84-92.

7. Mitra A, Pramanick P., Zaman S. and Mitra A. (2020b). Impact of COVID-19 Lockdown on the Ichthyoplankton community in and around Haldia Port-cum-Industrial complex. NUJS Journal of Regulatory Studies. April Special Issue. 64-68.

8. Pal N., Barman P., Das S., Zaman S., and Mitra A.(2020). Status of brackish water phytoplankton during COVID-19 lockdown phase. NUJS Journal of Regulatory Studies. April Special Issue. 83-86.

9. Pulla P. (2020). Covid-19: India imposes lockdown for 21 days and cases rise. BMJ. $368:$ m 1251 . ht tp s://d o i.org/ 10.1136/bmj.m1251

10. Roy N., Pal A. and Chaube R. (2020). Covid 19: A Systematic Approach to Combat the Deadly Virus. International Journal of Biological Innovations. 2 (2): 88-94. https://doi.org/ 10.46505/IJBI.2020.2202

11. Singhal T. (2020). A Review of Coronavirus Disease-2019 (COVID-19). Indian Journal of Paediatrics. 87(4): 281-286. https://doi.org/ 10.1007/s12098-020-03263-6
12. Srivastava B. and Reddy P. B. (2020). Assessment of KAP (Knowledge, Attitude and Practice) of University students towards Prevention of Covid-19. International Journal of Biological Innovations. 2 (2): 117-125. https://doi.org/10.46505/IJBI.2020.2206

13. Verma A.K. and Prakash S. (2020a). Impact of Covid-19 on Environment and Society. Journal of Global Biosciences. 9 (5): 7352-7363.

14. Verma A.K. and Prakash S. (2020b). E-wastes and their impact on environment and public health. International Journal of Applied Research. 6(9): 164-168.https://doi.org/ 10.22271/allresearch.2020.v6.i9c.7111

15. Wang T. and Su M. (2020). A preliminary assessment of the impact of COVID-19 on environment - A case study of China. The Science of the total environment. 728:138915. https://doi.org/10.1016/j.scitotenv.2020.13891 5

16. Yu H., Sun X., Solvang W.D. and Zhao X. (2020). Reverse Logistics Network Design for Effective Management of Medical Waste in Epidemic Outbreaks: Insights from the Coronavirus Disease 2019 (COVID-19) Outbreak in Wuhan (China). Int. J. Environ. Res. Public Health. 17(5):1770. https://doi.org/ 10.3390/ijerph17051770 